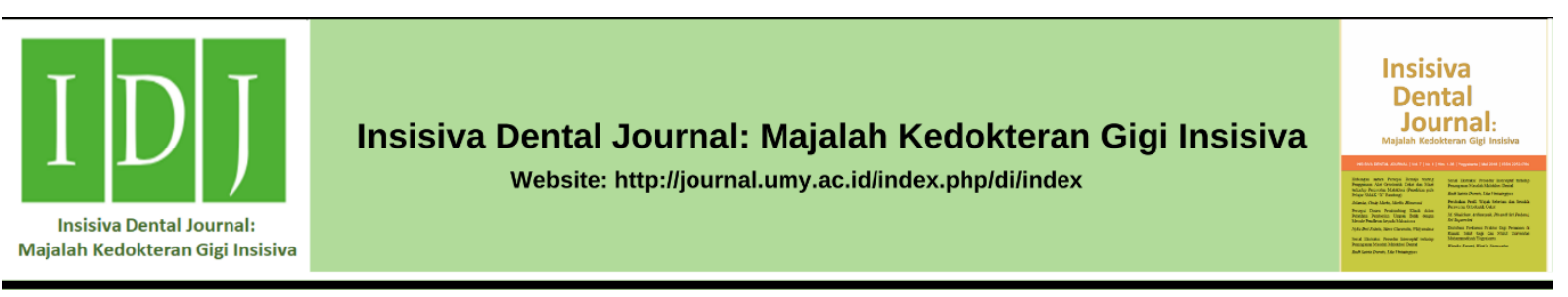

Research Article

\title{
Efektivitas Ekstrak Bawang Putih (Allium sativum) terhadap Bakteri Aggregatibacter actinomycetemcomitans Penyebab Gingivitis
}

Effectiveness of Garlic (Allium sativum) Extract against Aggregatibacter actinomycetemcomitans as an Etiology of Gingivitis

Triagus Nursasongko Sutiyono ${ }^{1}$, Risyandi Anwar,", ${ }^{2}$ Zita Aprillia ${ }^{2}$

${ }^{1}$ Fakultas Kedokteran Gigi, Universitas Muhammadiyah Semarang, Jalan Kedungmundu No 22 Semarang, Indonesia.

${ }^{2}$ Departemen Kedokteran Gigi Anak, Fakultas Kedokteran Gigi, Universitas Muhammadiyah Semarang, Jalan Kedungmundu No 22 Semarang, Indonesia.

Received date: July $31^{\text {st }}, 2019$; reviewed date: August $10^{\text {th }}, 2019$; revised date: August $26^{\text {th }}, 2019$; accepted date: October $31^{\text {st }}, 2019$ DOI : $10.18196 /$ di. 8204

\begin{abstract}
Abstrak
Gingivitis merupakan tahap pertama dalam perkembangan penyakit periodontal, yang disebabkan oleh plak gigi. Bakteri yang ditemukan dalam plak tersebut adalah Aggregatibacter actinomycetemcomitans (Aa). Perawatan gingivitis dapat dilakukan dengan berkumur larutan chlorhexidine 0,2. Bawang putih (Allium sativum) mengandung senyawa allicin yang memiliki efek antibakteri. Tujuan Penelitian ini untuk mengetahui efektivitas ekstrak bawang putih (Allium sativum) terhadap penghambatan pertumbuhan bakteri Aa sebagai penyebab gingivitis. Penelitian true eksperimental laboratoris dengan rancangan penelitian "post-test only control group design". Pengujian kemampuan antibakteri ekstrak bawang putih dengan menggunakan metode difusi sumuran. Pembuatan ekstrak dengan metode maserasi dengan konsentrasi 12,5\%, 25\%, 50\%, dan chlorhexidine 0,2\% sebagai kontrol positif. Pengulangan dilakukan 6 kali setiap konsentrasi dilanjutkan pengamatan zona hambat bakteri. Hasil Penelitian menunjukkan nilai rerata zona hambat ekstrak bawang putih terhadap pertumbuhan bakteri Aa dengan konsentrasi 50\% sebesar 11,50 mm, konsentrasi 25\% sebesar 8,17 mm, dan kontrol positif sebesar 7,22 mm namun konsentrasi $12,5 \%$ tidak menghambat pertumbuhan bakteri Aa. Sehingga dapat disimpulkan bahwa konsentrasi 50\% merupakan konsentrasi paling efektif dalam menghambat pertumbuhan bakteri Aa.
\end{abstract}

Kata Kunci: Aggregatibacter actinomycetemcomitans; Ekstrak bawang putih; Gingivitis

\begin{abstract}
Gingivitis is the first stage in periodontal disease, caused by dental plaque. The bacteria found are Aggregatibacter actinomycetemcomitans (Aa). Treatment of gingivitis can be conducted by gargling a $0.2 \%$ solution of chlorhexidine. Garlic contains allicin compounds that have an antibacterial effect. This research aims to identify the effectiveness of garlic (Allium sativum) extract in inhibiting the growth of Aa as an etiology of gingivitis. This research used a true experimental laboratory with a post-test only control group design. The antibacterial ability of garlic extract was tested using a well diffusion method. The extract production was carried out by utilizing a maceration method with a concentration of $12.5 \%, 25 \%, 50 \%$, and chlorhexidine $0.2 \%$ as a positive control. Repetition was conducted 6 times at each concentration, followed by observation of bacterial inhibitory zones. The result showed that the average of the inhibitory zone of garlic extract against the growth of Aa bacteria with a concentration of $50 \%$ was $11.50 \mathrm{~mm}$, while the concentration of $25 \%$ was 8.17 $\mathrm{mm}$, and positive control was $7.22 \mathrm{~mm}$. The concentration of $12.5 \%$ did not inhibit the growth of Aa. It can be concluded that the concentration of $50 \%$ is the most effective concentration in inhibiting the growth of Aa.
\end{abstract}

Keywords: Aggregatibacter actinomycetemcomitans; Garlic extract; Gingivitis

*Corresponding author, e-mail: drg.risyandi@unimus.ac.id 


\section{PENDAHULUAN}

Penyebab utama gingivitis yaitu plak gigi yang berkaitan dengan kebersihan rongga mulut yang buruk. Salah satu bakteri yang ditemukan dalam plak tersebut diantaranya adalah Aggregatibacter actinomycetemcomitans (Aa). ${ }^{1}$ Gingivitis yang tidak dirawat dapat berlanjut menjadi periodontitis kronis yang menyebabkan kerusakan jaringan gingiva, sampai menimbulkan hilangnya perlekatan gigi dan tulang alveolar, sehingga gigi mudah terlepas. ${ }^{2}$

Gingivitis dapat dirawat secara mekanik atau kimiawi. Perawatan secara mekanik dapat dilakukan dengan scaling. ${ }^{3}$ Perawatan gingivitis secara kimiawi dapat dilakukan dengan cara kumur-kumur dengan larutan chlorhexidine 0,2\%." Penggunaan chlorhexidine 0,2\% memiliki efek samping seperti nyeri, sensasi terbakar, gangguan pengecapan dan diskolorisasi gigi. ${ }^{5}$

Bawang putih (Allium sativum) telah dikenal sebagai tanaman obat sejak sekitar tahun 300 SM oleh bangsa Cina, dan suku-suku pengelana Asia Tengah. ${ }^{6}$ Penelitian menunjukkan bahwa ekstrak air bawang putih memiliki aktivitas bakteriostatik terhadap bakteri Porphyromonas gingivalis dan Aggregatibacter actinomycetemcomitans, ${ }^{7}$ tetapi belum ada data spesifik yang menunjukkan efektivitas daya hambat ekstrak air bawang putih dibandingkan dengan chlorhexidine $0,2 \%$. Oleh sebab itu, peneliti tertarik untuk melakukan penelitian tentang efektivitas daya hambat ekstrak air bawang putih (Allium sativum) dibandingkan dengan chlorhexidine 0,2\% terhadap bakteri Aggregatibacter actinomycetemcomitans sebagai penyebab gingivitis pada anak.

\section{MATERIAL DAN METODE}

Penelitian ini menggunakan jenis penelitian true experimental, dengan rancangan penelitian post test only control group design. Pengujian kemampuan antibakteri ekstrak bawang putih dengan menggunakan metode difusi sumuran. Teknik sampling yang digunakan adalah metode simple random sampling. Sampel berupa bakteri Aa. Kriteria inklusi sampel yang digunakan pada penelitian ini adalah umbi bawang putih yang masih segar sebelum dan saat dilakukan penelitian, serta sudah dikupas dari kulitnya terlebih dahulu. Penelitian ini dilaksanakan di laboratorium kimia organik jurusan kimia FMIPA Universitas Jendral Achmad Yani (UNJANI) Bandung dan Laboratorium Mikrobiologi Universitas Muhammadiyah Semarang. Variabel bebas yang diteliti adalah ekstrak air bawang putih dengan konsentrasi $12,5 \%, 25 \%$, dan 50\% dengan kontrol positif chlorhexidine $0,2 \%$.

\section{Pembuatan ekstrak air bawang putih}

Umbi bawang putih dipotong tipistipis kemudian dihaluskan hingga menjadi pasta, dan timbang sebanyak $250 \mathrm{~g}$. Pasta bawang putih direndam dengan pelarut aquades $500 \mathrm{ml}$ dengan perbandingan antara bawang putih dan pelarut $1: 2$ dan didiamkan minimal 1 x 24 jam. Pemisahan maserat dengan kasa dilakukan untuk mendapatkan filtrat bawang putih. Filtrat dipekatkan dengan menggunakan vacuum rotary evaporator hingga diperoleh ekstrak kental. Pengenceran dilakukan untuk mendapatkan konsentrasi 12,5\%, $25 \%$ dan $50 \%$.

\section{Pembuatan kultur bakteri}

Sampel bakteri Aa diambil dari media Brain Heart Infusion (BHI) dengan menggunakan ose steril di atas api spiritus dan digoreskan ke media Mueller Hinton Agar (MHA) secara tipis-tipis. Selanjutnya cawan petri diinkubasi selama 24 jam dalam inkubator dengan suhu $37^{\circ} \mathrm{C}$. Pembuatan suspensi bakteri uji yang dibandingkan dengan 0,5 McFarland diambil $100 \mu \mathrm{l}$.

\section{Uji daya hambat pertumbuhan bakteri}

Metode uji daya hambat pertumbuhan bakteri yang digunakan dalam penelitian ini adalah metode difusi 
sumuran. Sebanyak 6 buah cawan petri yang berisi media MHA plate diinokulasi dengan bakteri Aa. Sebuah lubang berdiameter $8 \mathrm{~mm}$ dibuat tepat ditengah media agar yang telah diinokulasi secara tegak lurus. Ekstrak air diinjeksikan ke dalam lubang tersebut. Inkubasi semua cawan selama 1 x 24 jam dengan suhu $37^{\circ} \mathrm{C}$. Lakukan pada masing-masing kelompok uji dengan pengulangan masingmasing 6 kali. Lebar zona bening yang terbentuk dihitung dengan menggunakan jangka sorong. Lebar tersebut merupakan lebar zona hambat terhadap pertumbuhan bakteri Aa.

\section{HASIL}

Hasil penelitian uji daya hambat bakteri ekstrak air bawang putih terhadap pertumbuhan bakteri Aa menunjukkan adanya zona hambat yang disajikan pada Tabel 1 . Konsentrasi $25 \%$ memiliki ratarata lebar zona hambat terkecil, yaitu 8,17 $\mathrm{mm}$ dan konsentrasi $50 \%$ memiliki ratarata lebar zona hambat terbesar, yaitu 11,5 mm, sedangkan pada konsentrasi $12,5 \%$ tidak terbentuk zona hambat. Hal ini menunjukkan bahwa semakin tinggi konsentrasi ekstrak air bawang putih semakin besar pula daya hambat yang dimiliki terhadap bakteri Aa.

Setelah dilakukan uji normalitas dan uji homogenitas, data tidak berdistribusi normal dan tidak homogen sehingga dilakukan uji non-parametrik Kruskall-Wallis. Berdasarkan Tabel 2 hasil uji statistik Kruskall-Wallis diperoleh nilai $\mathrm{p}=0,000(\mathrm{p}<0,05)$, yang menunjukkan bahwa terdapat perbedaan yang signifikan pada keempat kelompok. Perbandingan zona hambat pada masing-masing kelompok perlakuan dapat diketahui dengan menggunakan uji Mann-Whitney. Hasil analisis post hoc dengan uji MannWhitney pada Tabel 3 menunjukkan bahwa perbandingan masing-masing kelompok uji memiliki nilai $\mathrm{p}<0,05$ yang berarti terdapat perbedaan daya hambat yang signifikan antara masing-masing kelompok uji.
Tabel 1. Hasil uji daya hambat bakteri

\begin{tabular}{ccccc}
\hline \multirow{2}{*}{ Replikasi } & \multicolumn{4}{c}{ Diameter Zona Hambat $\mathbf{( m m )}$} \\
\cline { 2 - 5 } & K+ & $\mathbf{1 2 , 5 \%}$ & $\mathbf{2 5 \%}$ & $\mathbf{5 0 \%}$ \\
\hline I & 7,33 & 0,00 & 9,00 & 12,00 \\
\hline II & 7,33 & 0,00 & 8,00 & 12,00 \\
\hline III & 7,00 & 0,00 & 8,00 & 10,00 \\
\hline IV & 7,67 & 0,00 & 8,00 & 11,00 \\
\hline V & 7,00 & 0,00 & 8,00 & 12,00 \\
\hline VI & 7,00 & 0,00 & 8,00 & 12,00 \\
\hline Rata-rata & 7,22 & 0,00 & 8,17 & 11,50 \\
\hline
\end{tabular}

Tabel 2. Uji Kruskall-Wallis

\begin{tabular}{ccccc}
\hline Kelompok & N & $\begin{array}{c}\text { Mean } \\
\text { Rank }\end{array}$ & Sig. & Ket. \\
\hline Kontrol + & 6 & 9.50 & & \\
$12,5 \%$ & 6 & 3.50 & .000 & Signifikan \\
$25 \%$ & 6 & 15.50 & & \\
$50 \%$ & 6 & 21.50 & & \\
\hline
\end{tabular}

Tabel 3. Uji Mann-Whitney

\begin{tabular}{|c|c|c|c|c|}
\hline & Kontrol + & $12,5 \%$ & $25 \%$ & $50 \%$ \\
\hline Kontrol + & - & .002 & .002 & .003 \\
\hline $12,5 \%$ & .002 & - & .01 & .002 \\
\hline $25 \%$ & .002 & .001 & - & .002 \\
\hline $50 \%$ & .003 & .002 & .002 & - \\
\hline
\end{tabular}

\section{PEMBAHASAN}

Penelitian ini dilakukan dengan menggunakan metode difusi sumuran yang berisi agen antimikroba. Hasil uji daya hambat bakteri menunjukkan bahwa semakin tinggi konsentrasi ekstrak bawang putih maka semakin tinggi pula daya hambat terhadap bakteri Aa. Hal ini sesuai dengan penelitian Wiryawan et al., yang menyebutkan bahwa semakin tinggi konsentrasi bawang putih, maka aktivitas anti bakterinya cenderung meningkat. ${ }^{8}$ Rata-rata lebar zona hambat kelompok kontrol positif chlorhexidine 0,2\% sebagai pembanding memiliki rata-rata yang lebih rendah yaitu $7,22 \mathrm{~mm}$ dibandingkan dengan zona hambat yang dihasilkan oleh kelompok ekstrak air bawang putih konsentrasi $25 \%$ dan $50 \%$ terhadap pertumbuhan bakteri Aa. Ekstrak air bawang putih mampu menghambat pertumbuhan bakteri Aa karena ekstrak air bawang putih mengandung senyawa organosulfur seperti flavonoid, dan allicin. ${ }^{9,11}$

$$
\text { Allicin (diallyl thiosulfinate) }
$$
merupakan salah satu senyawa 
organosulfur yang terdapat di dalam hancuran bawang putih segar, mempunyai bermacam-macam aktivitas mikrobia. ${ }^{9}$ Allicin tidak terdapat dalam bawang putih sebelum bawang putih ditumbuk atau dipotong. Perlukaan pada bawang putih akan mengaktifkan enzim alliinase yang akan memetabolisme alliin menjadi allicin. $^{12}$ Mekanisme antibakteri dari bawang putih masih perlu diteliti lebih lanjut, namun diduga dengan merusak dinding sel dan menghambat sintesis protein. Alisin mempunyai permeabilitas yang tinggi dalam menembus membran fosfolipid dinding sel bakteri. Gugus thiol pada allicin kemudian akan bereaksi dengan enzim-enzim yang mengandung sulfuhidril yang menyusun membran sel. Hal ini diduga dapat menyebabkan struktur dinding sel bakteri akan rusak dan mengalami lisis. ${ }^{8}$

\section{KESIMPULAN}

Ekstrak bawang putih konsentrasi 50\% merupakan konsentrasi paling efektif dalam menghambat pertumbuhan bakteri Aa.

\section{DAFTAR PUSTAKA}

1. Newman, M. G. et al. Carranza's Clinical Periodontology. 11 ed. Missouri: Elsevier Saunders. 2012.

2. Nowicki, E. M. et al. Microbiota and Metatranscriptome Changes Accompanying the Onset of Gingivitis, mBio, 2018; 9(2): 1-17.

3. Karimbux, N. Clinical Cases in Periodontics. Chichester: WileyBlackwell. 2012.

4. Biswas, G. et al. "Evaluation of the Efficacy Of $0.2 \%$ Chlorhexidine versus Herbal Oral Rinse on Plaque Induced Gingivitis- A Randomized
Clinical Trail," IOSR-JNHS, 2014; 3(2): 58-63.

5. Kaur, P. et al. "Evaluation and Comparison of Short Term Side Effects Of $0.2 \%$ and $0.12 \%$ Chlorhexidine Mouthwash," JAMDSR, 2015; 3(3): 26-28.

6. Alam, M. K., Hoq, M. O. dan Uddin, M. S. "Medicinal Plant Allium sativum a Review," J Med Pla Stu, 2016; 4(6): 72-79.

7. Shetty, S. et al. "An In-vitro Evaluation of the Efficacy of Garlic Extract as an Antimicrobial Agent on Periodontal Pathogens: A Microbiological Study," $A Y U, 2013$; 34(4): 445-451.

8. Wiryawan, K. G., Suharti, S. dan Bintang, M. "Kajian Antibakteri Temulawak, Jahe dan Bawang Putih terhadap Salmonella typhimurium serta Pengaruh Bawang Putih terhadap Performans dan Respons Imun Ayam Pedaging," Media Peternakan, 2005; 2(2): 52-62.

9. Hernawan, U. E. dan Setyawan, A. D. "Review: Senyawa Organosulfur Bawang Putih (Allium sativum L.) dan Aktivitas Biologinya," Biofarmasi, 2003; 1(2): 65-76.

10. Cushnie, T. P. T. dan Lamb, A. J. "Review: Antimicrobial Activity of Flavonoids," Int J Antimicrob Agents, 2005; 26(5): 343-356.

11. Sabir, A. "Pemanfaatan Flavonoid di Bidang Kedokteran Gigi," Dental J. FKG-Unair, 2003; 36: 81-87.

12. Londhe, V. P. et al. "Review Role of Garlic (Allium sativum) in Various Diseases: An Overview," JPRO, 2011; 1(4): 129-134. 